\title{
Two adventive species of European Chrysomelidae (Coleoptera) new to North America: Cryptocephalus moraei (Cryptocephalinae) and Psylliodes dulcamarae (Galerucinae: Alticini), and the origins of adventive Chrysomelidae in Canada and United States of America
}

\author{
Hume B. Douglas ${ }^{1 \star}$ (D), Stéphane Dumont ${ }^{2}$, Karine Savard ${ }^{1}$, and Claude Chantal ${ }^{3}$ \\ ${ }^{1}$ Canadian National Collection of Insects, Arachnids and Nematodes, Agriculture and Agri-Food Canada, Ottawa, K1A 0C6, \\ Canada, ${ }^{2}$ Département de biologie et de biotechnologies, Collège Ahuntsic, 9155 rue Saint-Hubert, Montréal, H2M 1Y8, \\ Québec, Canada, and ${ }^{3} 302$ rue Gabrielle-Roy, Varennes, J3X 1L8, Québec, Canada \\ ${ }^{\star}$ Corresponding author. Email: Hume.Douglas@canada.ca
}

(Received 14 October 2020; accepted 17 February 2021; first published online 17 June 2021)

\begin{abstract}
First North American records are presented for Cryptocephalus moraei (Linnaeus, 1758) (Coleoptera: Cryptocephalinae) and Psylliodes dulcamarae (Koch, 1803) (Coleoptera: Galerucinae: Alticini), as confirmed by morphology and DNA barcoding. Additional information is presented about phenology and host use for C. moraei, the first European Cryptocephalinae to be found elsewhere as conclusively adventive. Cryptocephalus moraei is expected to have no ecological impact on its host, the adventive Hypericum perforatum Linnaeus (Hypericaceae). However, P. dulcamarae, the second recently discovered flea beetle associated with the adventive Solanum dulcamara Linnaeus (Solanaceae), probably does harm that host. Both species are hypothesised to have arrived from Europe with woody plant material imported with soil during 1960-1965. A literature review of introduced Chrysomelidae found that Canada and the United States of America are together home to 68-78 species of adventive Chrysomelidae. All non-Bruchinae species among these are both native to Europe and occur either in Canada or both Canada and United States of America, except for intentionally introduced biological control agents and two species that feed on Eucalyptus L'Héritier de Brutelle (Myrtaceae). This suggests a dominant role of accidental introductions of cool-climate European species in recent unplanned additions to the fauna of leaf-feeding Chrysomelidae in North America.
\end{abstract}

\section{Introduction}

Leaf beetles are drivers of ecological change in terrestrial biomes, acting as plant pests, biological control agents, and elsewhere as abundant herbivores (Myers and Sarfraz 2017). Québec, Canada has a tradition of collaboration between professionals and skilled amateur collectors in documenting its insect fauna, including economically important species (e.g., de Tonnancour et al. 2017). Here, we report establishment of two additional species of adventive Chrysomelidae found by independent scientific collectors in and near cities in Québec.

The first, Cryptocephalus moraei (Linnaeus, 1758) (Coleoptera: Cryptocephalinae), is native throughout Europe and western Asia (Lopatin et al. 2010). It has been found there in

Subject editor: Derek Sikes

(c) The authors, and Her Majesty, the Queen, in right of Canada, as represented by the Minister of Agriculture and Agri-Food Canada, 2021. Published by Cambridge University Press on behalf of the Entomological Society of Canada. This is an Open Access article, distributed under the terms of the Creative Commons Attribution licence (http://creativecommons.org/licenses/by/4.0/), which permits unrestricted re-use, distribution, and reproduction in any medium, provided the original work is properly cited. 
association with Hypericum perforatum Linnaeus (Hypericaceae), or St John's-wort (Rheinheimer and Hassler 2018). The second, Psylliodes dulcamarae (Koch, 1803) (Coleoptera: Galerucinae: Alticini), is native to western Eurasia, including Europe, Anatolia, Kazakhstan, Mongolia, and eastern Siberia (Döberl 2010). It has primarily been associated in Europe (Rheinheimer and Hassler 2018) with Solanum dulcamara Linnaeus (Solanaceae). We also discuss our findings in the context of the diversity and origins of accidentally introduced Chrysomelidae in North America.

\section{Methods}

Co-authors CC and SD collected specimens during independent insect-collecting activities. CC noted that neither species matched known North American species and sent specimens to co-author HD for identification through the Agriculture and Agri-Food Canada National Identification Service, Canadian National Collection of Insects, Arachnids and Nematodes (Ottawa, Ontario, Canada). SD learned about the discovery of Cryptocephalus moraei from CC and recognised that he also had specimens of C. moraei from Québec. SD also searched near Montréal, Québec for additional specimens and further ecological associations during the summers of 2019 and 2020. Associated plants were identified visually, in some cases with supporting photographs. HD searched for specimens at three sites with Hypericum in Ottawa, Ontario, Canada during summer 2020. Specimens are deposited in the following Canadian insect collections: Claude Chantal Insect Collection (private collection), Varennes, Québec, Canada; Pierre de Tonnancour Insect Collection (private collection), Terrasse Vaudreuil, Québec, Canada; Stéphane Dumont Insect Collection (private collection), Montréal, Québec, Canada; and the Canadian National Collection of Insects Arachnids and Nematodes, Ottawa Ontario, Canada. HD and KS dissected and compared specimens to North American (White 1968; Quinn 2017) and European (Burlini 1955; Doguet 1994; Nadein 2010) taxonomic literature and expert-managed Internet sites (Borowiec 2010-2020) and identified the Canadian National Collection specimens, also sending images of Canadian specimens of C. moraei to J. Bezděk (Mendel University, Brno, Czech Republic) and images of P. dulcamarae to M. Gikonyo (Max Planck Institute for Chemical Ecology, Germany), who performed independent photo-based identifications.

For DNA analysis, a single leg was detached from each specimen and was placed in a well in a 96-well microplate prefilled with $10 \mu \mathrm{L}$ of $96 \%$ ethanol. Each specimen was also photographed, and the resulting image was uploaded to the Barcode of Life Database (BOLD; Ratnasingham and Hebert 2007) along with the label data. The DNA extraction, polymerase chain reaction amplification, and Sanger sequencing of the cytochrome oxidase subunit 1 barcode region were performed for all specimens at the Centre for Biodiversity Genomics (University of Guelph, Guelph, Ontario, Canada), using standard protocols as outlined by Pentinsaari et al. (2019). Primers LepF1 and LepR1 (Hebert et al. 2004) were used for polymerase chain reaction amplification. Sequences were obtained through unidirectional analysis. Details on the polymerase chain reaction and sequencing protocols for each specimen are provided in the public BOLD dataset information below.

Detailed collection information for each specimen, including both DNA-barcoded material and other specimen records, as well as GenBank accession numbers for the barcode sequences, are listed in the text. All sequences, details on polymerase chain reaction and sequencing primers, photographs, and full collection data for the DNA-barcoded specimens are available through a public dataset on BOLD (https://doi.org/dx.doi.org/10.5883/DS-CRYPPSYL).

The total number of adventive Chrysomelidae in North America north of Mexico has not been defined, but Klimaszewski et al. (2020) found Canada hosted 61 species of adventive Chrysomelidae. The lack of current total estimates for North America may originate from a history of publications for Bruchinae that are separate from the remainder of Chrysomelidae 
and the fact that the catalogue by Riley et al. (2003) did not focus primarily on adventive species. Here, we review the recent literature to assemble a list of adventive Chrysomelidae for North America.

\section{Results and discussion}

\section{Cryptocephalus moraei}

The external morphology and genitalia of Canadian specimens closely matched Burlini's (1955) taxon concept of C. moraei, as based on European specimens; J. Bezděk also confirmed our identification.

Cryptocephalus moraei was found at the following localities in Canada, Québec: Verchères, Varennes, 16.vii.2017, Claude Chantal 1 ex.; Laval, Rue St-Boniface, 45.5964, -73.6827, 6.vii.2013, swimming pool, 1 ex., S. Dumont; Laval, Boisé Papineau, 45.6078, -73.6849, 28.vi.2014, mixed meadow with Equisetum arvense-Potentilla reptans, 3 ex., S. Dumont; same except, 15.vii.2019, 6 ex. (including DNA-barcoded specimen CCDB19514_CNC_P1A10, CNC1053107; GenBank: MW564587); same except, 22.vii.2019, 5 ex. and Lotus corniculatus, 1 ex.; Montréal, Parc ZotiqueRacicot, 45.5416, -73.6831, 24.vii.2015, Plantago lanceolata, 1 ex., S. Dumont; same except, 45.5426, -73.6903, 11.vii.2018, Cirsium arvense, 1 ex.; same except 45.5432, -73.6916, 17.vii.2019, Medicago lupulina, 4 ex. (including DNA-barcoded specimen CCDB19514_CNC_P1A9, CNC1053106; GenBank: MW564586); same except, 18.vii.2019, 1 ex. + Hypericum perforatum, 1 ex.; same except, 24.vii.2019, Medicago lupulina, 6 ex.; same except, 30.vii.2019, 3 ex.; same except, 1.viii.2019, 1 ex; same except 14.vi.2020, 2 ex.; same except 19.vi.2020, 1 ex. + Montréal, Boisde-Boulogne train station, 45.5407, -73.6754, Potentilla reptans, 6 ex.; Montréal, Parc Zotique-Racicot, 45.5432, -73.6916, 28.vi.2020, Medicago lupulina, 13 ex.; same except, 5.vii.2020, 6 ex., S. Dumont with P. de Tonnancour; same except, 18.vii.2020, 7 ex., S. Dumont; same except, 22.vii.2020, 2 ex.; same except, 24.vii.2020, 1 ex.; same except, 11.viii.2020, 1 ex.

Specimens were swept from Equisetum Linnaeus (Equisetaceae) and Potentilla Linnaeus (Rosacea) stands and from individual plants of Hypericum Linnaeus (Hypericaceae), Lotus Linnaeus (Fabaceae), Medicago Linnaeus (Fabaceae) (Fig. 1D), Plantago Linnaeus (Plantaginaceae), and Trifolium Linnaeus (Fabaceae) growing in dry-mesic meadows on disturbed rocky subsoil (Fig. 1), with Cryptocephalus venustus (Fabricius, 1787) also present. No C. moraei specimens were found in wet-soil parts of one of the same sites. The earliest collection year for C. moraei was 2013 in Laval, Québec. Specimens from the Montréal, Québec sites were collected between 14 June and 11 August 2020. Searches were not conducted during 3-13 August 2019 or between 31 July and 7 August 2020. Searches by SD on 14, 18, and 31 August 2019, on 17, 20, 24, and 30 May 2020, and on 16 and 19 August 2020 yielded no specimens. The distances between collection site clusters were 36 and seven kilometres in the Montréal area, including the south shore of the St. Lawrence River and the two largest islands of the Hochelaga Archipelago. Collection of 74 specimens in three areas over seven years suggests that C. moraei is established at multiple sites in Canada. Searches at three similar sites in central Ottawa, Ontario, Canada yielded no specimens. No wider survey has been conducted to determine the full range of this species in North America.

Cryptocephalus moraei can be distinguished from other North American and European Cryptocephalus by body length, 3-5 mm, with nonmetallic and mainly black dorsal and ventral colouration (Fig. 2A, B), body glabrous dorsally; head with pale markings on frons (X-shaped in male, Fig. 2C; female with two red longitudinal lines in most); pronotum pale at anterior edge and hind angles in male (Fig. 2A, C, D) and in some females, pronotal lateral carina not visible in dorsal view, punctures not forming striae; elytra striate with pale patches near humeri and apices (Fig. 2A, B), humeral pale patches not reaching elytral base or suture; legs with ventral side of profemora pale (Fig. 2A), tibiae and tarsi pale (modified from 

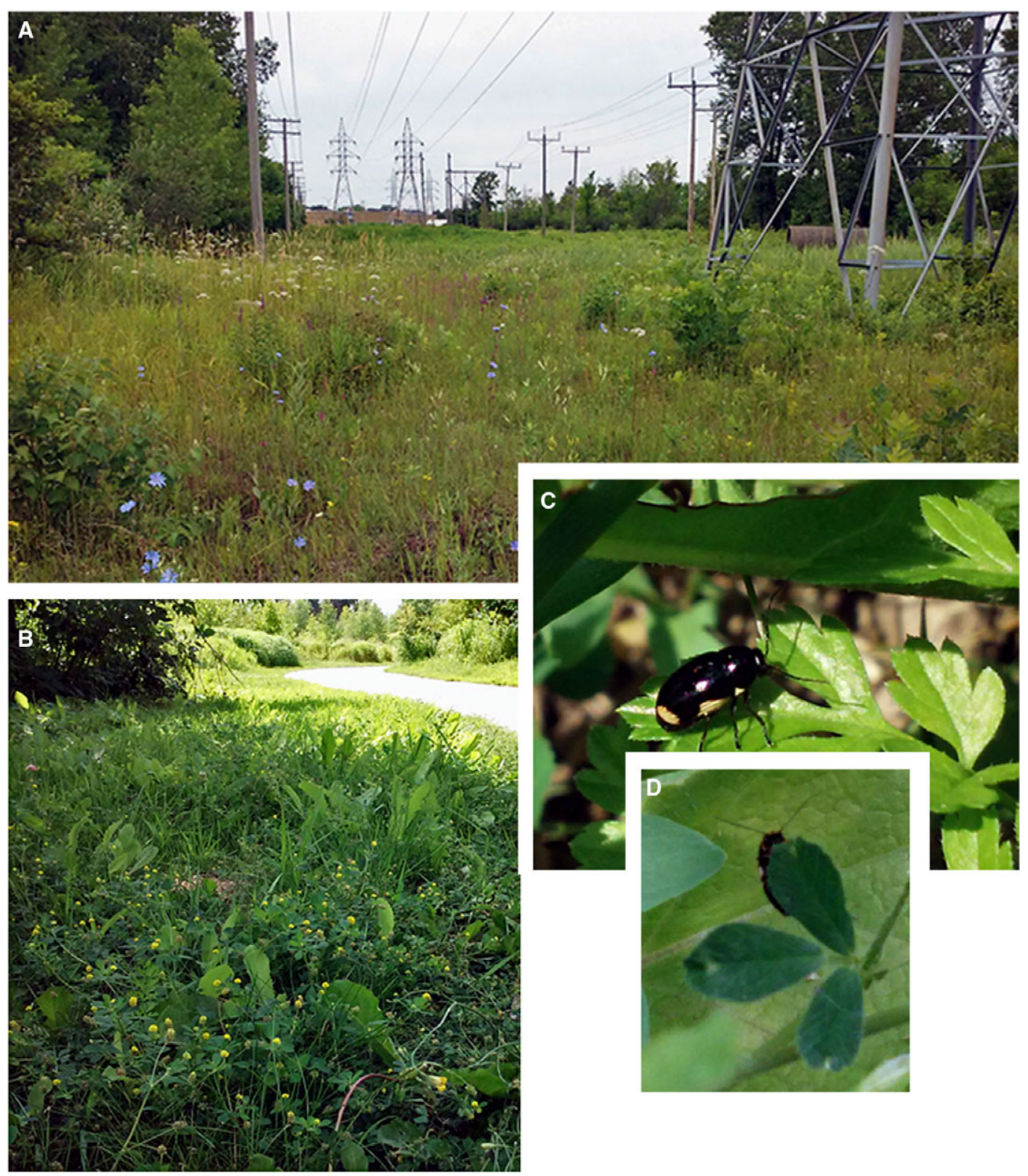

Fig. 1. Habitat and resting plants used by Cryptocephalus moraei from Québec, Canada: A, Boisé Papineau, Laval, Québec, Canada; B, Parc Zotique-Racicot, Montréal, Québec; C, on leaf (possibly of Pastinaca sativa Linnaeus (Apiacieae)); and D, under leaf of Medicago lupulina.

Mohr 1966). The aedeagal shape (Fig. 3A-C) also distinguishes this from previously illustrated North American Cryptocephalus species (White 1968). The prosternum also has pale peg-like postcoxal projections (Fig. 2D) not observed in other North American Cryptocephalinae. Females can be distinguished from males by dark anterior edge of the pronotum and a mesal depression on ventrite 5. The eastern North American Cryptocephalus quadruplex Newman, 1841 is similar, but pale markings are absent from the head and pronotum, and most specimens have the humeral pale spot reaching the elytral base. 

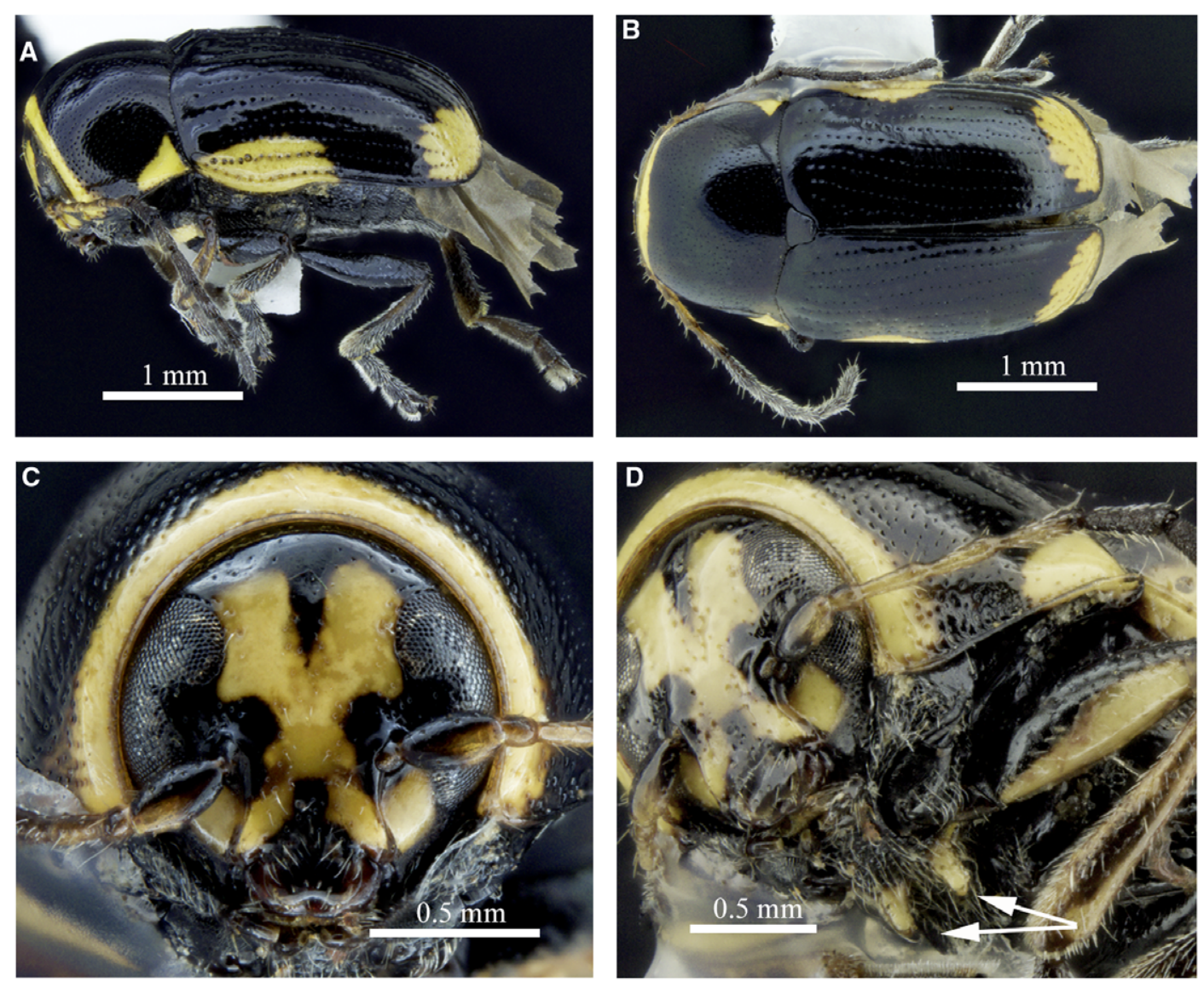

Fig. 2. Morphology of a male of Cryptocephalus moraei from Québec, Canada: A, lateral habitus; B, dorsal habitus; C, anterior view of head; and $\mathbf{D}$, ventrolateral view of prosternum with arrows to postcoxal projections.

Although C. moraei is primarily associated with Hypericum perforatum Linnaeus (Hypericaceae) (also called St John's-wort; Rheinheimer and Hassler 2018), only one Canadian adult specimen was also found on $H$. perforatum. Hypericum perforatum is an adventive weed in North America that has been subject to biological control efforts. However, C. moraei is not expected to substantially damage Hypericum plants because its larvae consume senescent leaves (Rheinheimer and Hassler 2018).

Analysis of the two DNA-barcoded Canadian specimens of C. moraei through the BOLD Identification Engine resulted in a $98.78 \%$ match with Cryptocephalus moraei. The BOLD Barcode Index Number (Ratnasingham and Hebert 2013) cluster assignments were not available for our specimens at the time of publication. Comparison of sequences of our specimens to publicly available specimens from European barcoding initiatives (Pentinsaari et al. 2014; Hendrich et al. 2015) indicated sequence divergences of $1.2-4.3 \%$ among 26 specimens from barcode index numbers ACE2080 and AAN3893. The barcodes from the Canadian specimens were closer to barcode index number ACE280, with specimens from Finland and Estonia, than to barcode index number AAN3893, with specimens from Germany, Italy, Spain, France, Austria, Netherlands, and Norway. Clustering of the Canadian specimens within European sequences of C. moraei is consistent with our morphological identification. 
A

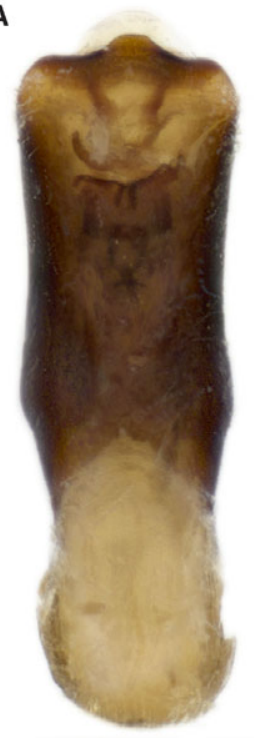

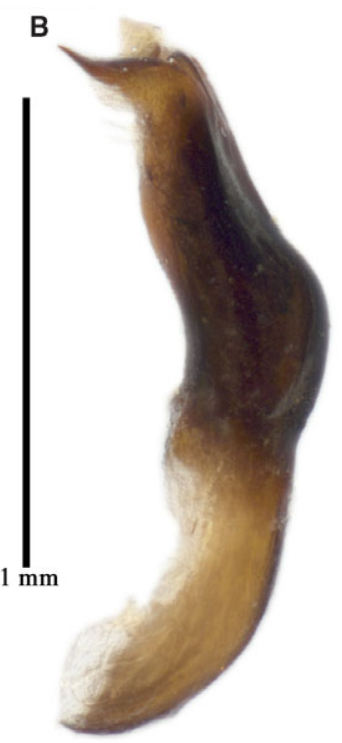

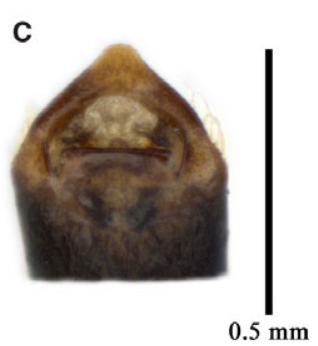

D

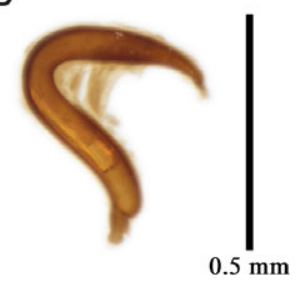

Fig. 3. Genitalia of Cryptocephalus moraei from Québec, Canada: A, aedeagus, dorsal view; B, aedeagus, lateral view; C, aedeagus apex in apico-dorsal view; and D, spermatheca.

\section{Psylliodes dulcamarae}

The external morphology and male genitalia of Canadian specimens closely matched Nadein's (2010) taxon concept of P. dulcamarae, as based on European specimens; M. Gikonyo also confirmed our identification. We identified Psylliodes specimens as P. dulcamarae using Nadein (2010) and Doguet (1994). They also matched Canadian National Collection specimens identified by Doguet in body shape, frons morphology and colour pattern, punctation of the pronotum and elytra, aedeagus shape, and spermatheca shape. The spermatheca matches the image published by Doguet (1994, Fig. 223i) in the shapes of the pump and duct; however, the receptacle is about one-third narrower than in the specimen illustrated. This suggests that there may be undocumented spermathecal receptacle-shape variability in the native range of this species.

Analysis of the DNA-barcoded Canadian specimen of $P$. dulcamarae through the BOLD Identification Engine resulted in a $99.69 \%$ match with Psylliodes dulcamarae. The BOLD barcode index number assignments were not available for our specimens at the time of publication.

Comparison of sequences of our specimen to specimens from the German Barcode of Life project (Hendrich et al. 2015) indicated sequence divergences of $0.3-0.9 \%$ among the eight specimens with publicly available data compared. This result is consistent with morphological identification of $P$. dulcamarae.

One author (CC) found $P$. dulcamarae at the following localities in Canada, Québec: Verchères, Varennes, 9.vi.2010, 1 ex.; 15.v.2012, 2 ex.; 27.vi.2013, 1 ex.; 11.v.2014, 1 ex.; 21.v.2014, 1 ex.; 23.v.2014, 2 ex.; 11.vi.2014, 4 ex.; 30.vi.2014, 1 ex.; 8.vii.2014, 1 ex.; 30.vii.2014, 2 ex.; 15.v.2015, 1 ex. (DNA-barcoded specimen CCDB19514_CNC_P1A11, CNC1053108; GenBank: MW564584); 18.v.2015, 1 ex.; 1.vi.2015, 1 ex.; 7.vi.2015, 2 ex.; 2.vii.2015, 1 ex.; 24.v.2018, 1 ex.; Boucherville, woodland edge by industrial area, 45.55, -73.42, 25.v.2012, 3 ex.; same data except 19.v.2014, 1 ex. Collection of 27 specimens from two sites on the south shore of the St. Lawrence River, Québec separated by $25 \mathrm{~km}$ over eight years suggests that populations of $P$. dulcamarae are established in Canada. No survey has been conducted to determine the full range of this species in North America. 

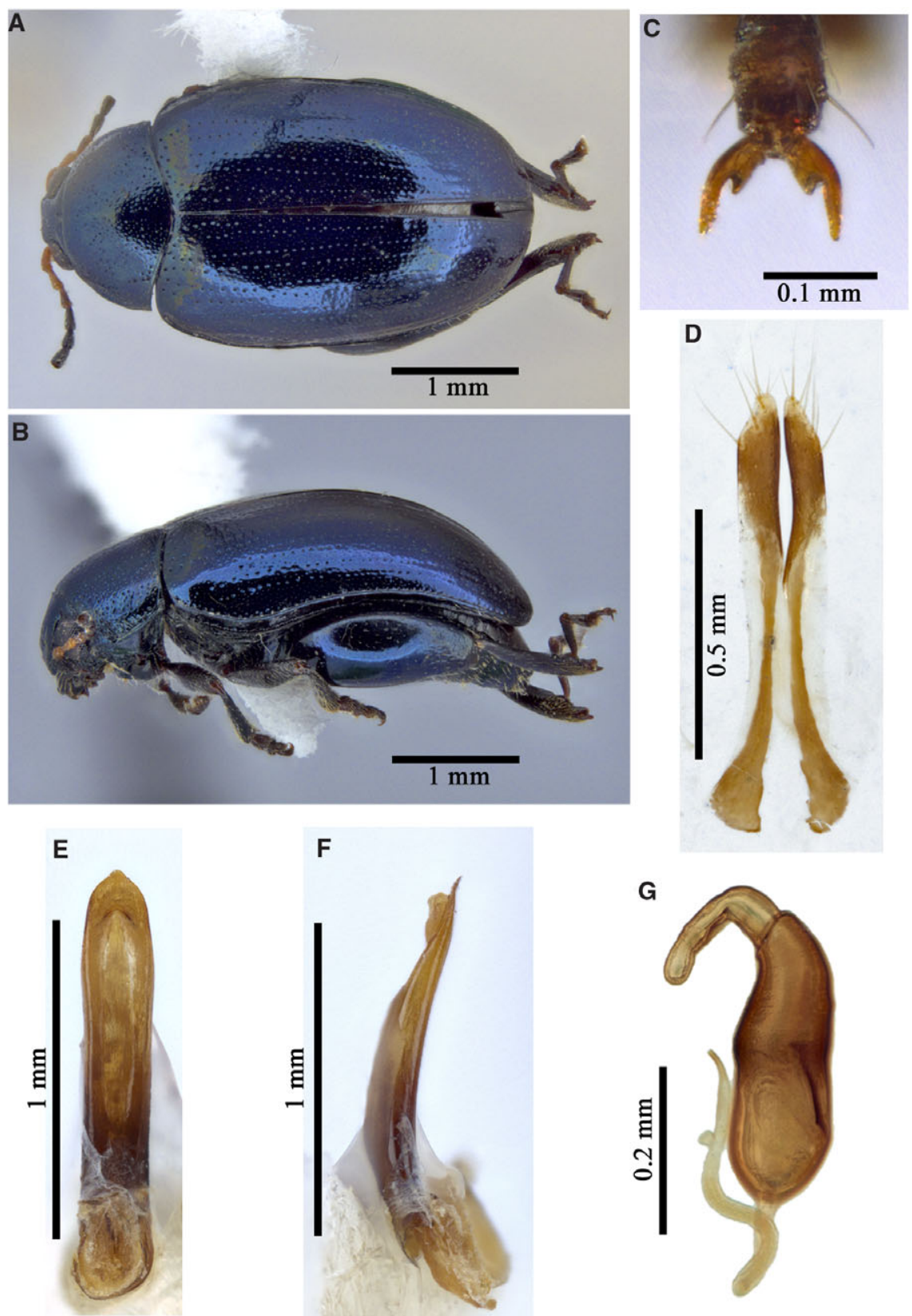

Fig. 4. Morphology of Psylliodes dulcamarae from Québec, Canada: A, male dorsal habitus; B, male lateral habitus; C, male tarsal claw; D, vaginal palpi; E, aedeagus, dorsal view; F, aedeagus, lateral view; and G, spermatheca.

Genus Psylliodes requires taxonomic revision; however, $P$. dulcamarae can be distinguished from other eastern North American Psylliodes by the following combination of characters: metallic-blue colouration and uniformly dark legs (Fig. 4A, B). Its aedeagus and female genitalia also appear unique among described North American species (Fig. 4D-G).

Psylliodes dulcamarae has primarily been associated in Europe with Solanum dulcamara (Rheinheimer and Hassler 2018), a species with red berries that are probably toxic to humans 
in large quantities (Alexander et al. 1948; Hornfeldt and Collins 1990) and possibly also to livestock (Waggy 2009). Although Solanum dulcamara is not native to North America, it has apparently not been a subject of biological control research efforts (Mason and Huber 2002; Mason and Gillespie 2013). It has perhaps not received biological control research attention because of its low stand density in nature and because it is congeneric with potato, tomato, and peppers. Its relatedness to cultivated vegetables presents a risk that herbivorous biological control agents could also attack crops. However, to date, P. dulcamarae has not been found associated with important damage to crop species. This species may benefit agriculture, human safety, and native plant communities in North America by harming $S$. dulcamara plants.

\section{Adventive species biology}

Interestingly, P. dulcamarae is the second pest of Solanum dulcamara to be discovered recently in North America. Deczynski $(2014,2019)$ recently reported Epitrix pubescens (Koch, 1803) (Coleoptera: Chrysomelidae) from the northeastern United States of America and eastern Canada, with specimens known from as early as 1975. It seems likely that these two flea beetle species that feed on the same host may have come to North America along the same trade pathway. One possible pathway for such introductions is importation of woody plants with soil. For example, some populations of Elateridae (Coleoptera) that were detected as larvae in shipments of woody plants shipped with soil during 1960-1965 have only recently been detected as adventive in North American cities (Douglas 2011). Many flea beetle larvae also develop around the roots of weedy hosts, which are likely to also have been shipped to North America in soil with woody ornamental plants.

Cryptocephalus moraei is the first Palearctic species of Cryptocephalinae introduced elsewhere in the world (although the Nearctic Diachus auratus Fabricius, 1801 now has a cosmopolitan distribution; Reid 1988; Regalin and Medvedev 2010; Schöller et al. 2010). Cryptocephalinae with larvae mainly inhabiting leaf litter are probably less prone to accidental transport by humans via plant tissue than are herbivores feeding on or in growing plant tissues. Finding such an introduction in a northeastern North American city is also consistent with the former practice of importing European plants in soil to North America.

\section{Origins of adventive Chrysomelidae in North America}

Before these findings, Canada and the United States of America were together known to host 66-76 species of adventive Chrysomelidae (Table 1). This estimate is based on 44 adventive and possibly adventive Chrysomelidae reported from North America by Riley et al. (2003). Riley et al. (2003) also reported three additional nonnative species of uncertain populationestablishment status in North America. Kingsolver (2004) added 14 adventive Bruchinae and two North American Bruchinae of possible adventive origins to these numbers. Klimaszewski et al. (2020) reviewed recent records of adventive Chrysomelidae in Canada (including recent additions by Pentinsaari et al. 2019), finding seven additional species for the North American fauna. Five additional species are reported from the United States of America in four other publications (see Table 1). These sources, together with our findings, indicate that 68-78 species of adventive Chrysomelidae are known from Canada and the United States of America. Of these, 51-59 are known from Canada, and 56-66 are known from the United States of America. These numbers include 21 species intentionally introduced as biological control agents. The numbers also capture uncertainty about the presence of six nonnative species and about nonnative status of four recorded species. Unverified Internet reports suggest that at least two additional species of Palaearctic Chrysomelidae occur in the United States of America. It is also likely that some species reported from only the United States of 
Table 1. Adventive Chrysomelidae reported from Canada and the United States of America. Unless noted otherwise, all are established, accidentally introduced nonnative species that are present in both countries. References cited are numbered as follows: (1) Riley et al. 2003; (2) Clark et al. 2004; (3) Kingsolver 2004; (4) Hoebeke et al. 2009; (5) Overholt et al. 2009; (6) Tracy and Robbins 2009; (7) Overholt et al. 2016; and (8) Klimaszewski et al. 2020.

\begin{tabular}{|c|c|c|}
\hline Subfamily & Name & Notes \\
\hline Bruchinae & Acanthoscelides modestus (Sharp, 1885) & Not Canada (3) \\
\hline Bruchinae & Acanthoscelides obtectus (Say, 1831) & Native? $(3 ; 8)$ \\
\hline Bruchinae & Amblycerus nigromarginatus (Motschulsky, 1874) & Not Canada (3) \\
\hline Bruchinae & Amblycerus obscurus (Sharp, 1885) & Not Canada (3) \\
\hline Bruchinae & Borowiecius ademptus (Sharp, 1886) & Not Canada (3) \\
\hline Bruchinae & Bruchidius cisti (Fabricius, 1775) & $(3 ; 8)$ \\
\hline Bruchinae & Bruchidius terrenus (Sharp, 1886) & Not Canada (4) \\
\hline Bruchinae & Bruchidius villosus (Fabricius, 1792) & $(3 ; 8)$ \\
\hline Bruchinae & Bruchus brachialis Fåhraeus, 1839 & $(3 ; 8)$ \\
\hline Bruchinae & Bruchus pisorum (Linnaeus, 1758) & $(3 ; 8)$ \\
\hline Bruchinae & Bruchus rufimanus (Boheman, 1833) & $(3 ; 8)$ \\
\hline Bruchinae & Callosobruchus chinensis (Linnaeus, 1758) & $(3 ; 8)$ \\
\hline Bruchinae & Callosobruchus maculatus (Fabricius, 1775) & $(3 ; 8)$ \\
\hline Bruchinae & Callosobruchus phaseoli (Gyllenhal, 1833) & Not Canada (3) \\
\hline Bruchinae & Callosobruchus pulcher Pic, 1922 & Not Canada (3) \\
\hline Bruchinae & Caryedon serratus (Olivier, 1790) & Not Canada (3) \\
\hline Bruchinae & Megacerus ripiphorus (Fahraeus, 1839) & Native? (3), not Canada (3) \\
\hline Cassidinae & Cassida azurea Fabricius, 1801 & $\begin{array}{l}\text { Biocontrol ( } 1 ; 8) \text {, not United States of } \\
\text { America }\end{array}$ \\
\hline Cassidinae & Cassida flaveola Thunberg, 1794 & Native? (8) \\
\hline Cassidinae & Cassida rubiginosa Muller, 1776 & $(1 ; 8)$ \\
\hline Cassidinae & Cassida viridis Linnaeus, 1758 & Not United States of America? (8) \\
\hline Cassidinae & Gratiana boliviana Spaeth, 1926 & Biocontrol (4), not Canada \\
\hline Chrysomelinae & Chrysolina hyperici (Forster, 1771) & Biocontrol $(1 ; 8)$ \\
\hline Chrysomelinae & Chrysolina quadrigemina (Forster, 1771) & Biocontrol $(1 ; 8)$ \\
\hline Chrysomelinae & Chrysolina staphylaea (Linnaeus, 1758) & Not United States of America \\
\hline Chrysomelinae & Chrysolina varians (Schaller, 1783) & Biocontrol, established? $(1 ; 8)$ \\
\hline Chrysomelinae & Gastrophysa polygoni (Linnaeus, 1758) & $(1 ; 8)$ \\
\hline Chrysomelinae & Paropsisterna m-fuscum (Boheman, 1859) & Not Canada (2) \\
\hline Chrysomelinae & Plagiodera versicolora (Laicharting, 1781) & $(1 ; 8)$ \\
\hline Chrysomelinae & Trachymela sloanei (Blackburn, 1896) & Not Canada \\
\hline Criocerinae & Crioceris asparagi (Linnaeus, 1758) & $(1 ; 8)$ \\
\hline Criocerinae & Crioceris duodecimpunctata (Linnaeus, 1758) & $(1 ; 8)$ \\
\hline Criocerinae & Lema cyanella (Linnaeus, 1758) & Biocontrol, established? $(1 ; 8)$ \\
\hline Criocerinae & Lilioceris cheni Gressit and Kimoto, 1961 & Biocontrol (7), not Canada \\
\hline
\end{tabular}


Table 1. (Continued)

\begin{tabular}{|c|c|c|}
\hline Subfamily & Name & Notes \\
\hline Criocerinae & Lilioceris lilii (Scopoli, 1763) & $(1 ; 8)$ \\
\hline Criocerinae & Oulema melanopus (Linnaeus, 1758) & $(1 ; 8)$ \\
\hline Cryptocephalinae & Cryptocephalus moraei (Linnaeus, 1758) & Present study, not United States of America \\
\hline Galerucinae & Agasicles hygrophila Selman and Vogt, 1971 & Biocontrol $(1 ; 8)$, not Canada \\
\hline Galerucinae & Altica carduorum (Guérin-Ménéville, 1858) & Biocontrol, established? $(1 ; 8)$ \\
\hline Galerucinae & Aphthona cyparissiae (Koch, 1803) & Biocontrol $(1 ; 8)$ \\
\hline Galerucinae & Aphthona czwalinae Weise, 1881-1893 & Biocontrol $(1 ; 8)$ \\
\hline Galerucinae & Aphthona flava Guillebeau, 1894 & Biocontrol $(1 ; 8)$ \\
\hline Galerucinae & Aphthona lacertosa Rosenhaur, 1840 & Biocontrol $(1 ; 8)$ \\
\hline Galerucinae & Aphthona nigriscutis Foudras, 1860 & Biocontrol $(1 ; 8)$ \\
\hline Galerucinae & Chaetocnema concinna (Marsham, 1802) & $(1 ; 8)$ \\
\hline Galerucinae & Chaetocnema hortensis (Geoffroy, 1785) & Not United States of America? (8) \\
\hline Galerucinae & $\begin{array}{l}\text { Diorhabda carinulata (Desbrochers des Loges, } \\
\text { 1870) }\end{array}$ & Biocontrol (6), not Canada \\
\hline Galerucinae & Diorhabda elongate (Brullé, 1832) & Biocontrol (6), not Canada \\
\hline Galerucinae & Epitrix pubescens (Koch, 1803) & $(8)$ \\
\hline Galerucinae & Longitarsus ferrugineus (Foudras, 1859) & $(1 ; 8)$ \\
\hline Galerucinae & Longitarsus flavicornis (Stephens, 1831) & Biocontrol, established? $(1 ; 8)$ \\
\hline Galerucinae & Longitarsus ganglebaueri Heikertinger, 1912 & Native? (8) \\
\hline Galerucinae & Longitarsus jacobaeae (Waterhouse, 1858) & Biocontrol $(1 ; 8)$ \\
\hline Galerucinae & Longitarsus lewisii Baly, 1874 & Not United States of America? (8) \\
\hline Galerucinae & Longitarsus luridus (Scopoli, 1763) & $(1 ; 8)$ \\
\hline Galerucinae & Longitarsus pellucidus (Foudras, 1859) & Not United States of America? \\
\hline Galerucinae & Longitarsus pratensis (Panzer, 1794) & $(1 ; 8)$ \\
\hline Galerucinae & Longitarsus quadriguttatus (Pontoppidan, 1763) & $\begin{array}{l}\text { Biocontrol }(1 ; 8) \text {, not United States of } \\
\text { America }\end{array}$ \\
\hline Galerucinae & Longitarsus rubiginosus (Foudras, 1859) & Not United States of America? \\
\hline Galerucinae & Longitarsus succineus (Foudras, 1859) & Not United States of America \\
\hline Galerucinae & Lythraria salicariae (Paykull, 1800) & Not United States of America (8) \\
\hline Galerucinae & Mantura chrysanthemi (Koch, 1803) & $(1 ; 8)$ \\
\hline Galerucinae & Neocrepidodera ferruginea (Scopoli, 1763) & Not United States of America? (8) \\
\hline Galerucinae & Neogalerucella calmariensis (Linnaeus, 1767) & Biocontrol $(1 ; 8)$ \\
\hline Galerucinae & Neogalerucella pusilla (Duftschmid, 1825) & Biocontrol $(1 ; 8)$ \\
\hline Galerucinae & Phyllotreta armoraciae (Koch, 1803) & $(1 ; 8)$ \\
\hline Galerucinae & Phyllotreta cruciferae (Goeze, 1777) & $(1 ; 8)$ \\
\hline Galerucinae & Phyllotreta punctulata (Marsham, 1802) & $(1 ; 8)$ \\
\hline Galerucinae & Phyllotreta striolata (Fabricius, 1801) & $(1 ; 8)$ \\
\hline Galerucinae & Psylliodes affinis (Paykull, 1799) & $(1 ; 8)$ \\
\hline
\end{tabular}


Table 1. (Continued)

\begin{tabular}{lll}
\hline Subfamily & Name & Notes \\
\hline Galerucinae & Psylliodes chalcomerus (Illiger, 1807) & Biocontrol, established?, not Canada (1) \\
\hline Galerucinae & Psylliodes chrysocephalus (Linnaeus, 1758) & Established? (8) \\
\hline Galerucinae & Psylliodes cucullatus (Illiger, 1807) & $(1 ; 8)$ \\
\hline Galerucinae & Psylliodes dulcamarae (Koch, 1803) & Present study, not United States of America \\
\hline Galerucinae & Psylliodes napi (Fabricius, 1792) & $(1 ; 8)$ \\
\hline Galerucinae & Psylliodes picinus (Marsham, 1802) & $(1 ; 8)$ \\
\hline Galerucinae & Pyrrhalta viburni (Paykull, 1799) & $(1 ; 8)$ \\
\hline Galerucinae & Sphaeroderma testaceum (Fabricius, 1775) & Not United States of America? (8) \\
\hline Galerucinae & Xanthogaleruca luteola (Muller, 1776) & $(1 ; 8)$ \\
\hline
\end{tabular}

America (northern parts) or only Canada also occur in the other country because detection surveys have not been done.

Except for seed-feeding Bruchinae, nearly all accidentally introduced species both originated in Europe and occur in Canada (Klimaszewski et al.2020). The exceptions to this are two species that feed on Australian Eucalyptus L'Héritier de Brutelle (Myrtaceae) that are known from southwestern United States of America and which may have been introduced intentionally (Paine et al. 2010). This abundance of European adventive species indicates that although Asia is the source of some important recent introductions of beetles in other families, most newly discovered adventive Chrysomelidae species in North America continue to originate from Europe. This is consistent with the hypothesis that recent discoveries of introduced species represent expanding populations of species established 50-60 years earlier via former trade-related introduction pathways carrying larger numbers of soil-dwelling insects. Findings of accidentally introduced species in Canada but not in adjacent areas of the United States of America suggest that the fauna of the northeastern United States of America may include several undocumented adventive chrysomeloid species.

Acknowledgements. The authors thank J. Bezděk (Mendel University, Brno, Czech Republic) for confirming identification of C. moraei and M. Gikonyo (Max Planck Institute for Chemical Ecology, Germany) for confirming identifications of $P$. dulcamarae. Thanks to J.-F. Landry (Agriculture and Agri-Food Canada) for methodological advice. The authors extend their thanks to M. Pentinsaari (University of Guelph), E.G. Riley (Texas A\&M University), and an anonymous reviewer for comments that helped improve the manuscript.

\section{References}

Alexander, R.F., Forbes, G.B., and Hawkins, E.S. 1948. A fatal case of solanine poisoning. British Medical Journal, 2: 518.

Borowiec, L. 2010-2020. The leaf beetles of Europe and the Mediterranean subregion. Checklist and iconography. Chrysomelidae. Department of Biodiversity and Evolutionary Taxonomy, University of Wroclaw, Poland. Available from http://www.biol.uni.wroc.pl/cassidae/ European\%20Chrysomelidae/index.htm [accessed 28 May 2020].

Burlini, M. 1955. Revisione dei Cryptocephalus italiani e della maggior parte delle specie di Europe (Col. Chrysomelidae). Memorie della Societa Entomologica Italiana, 34: 1-287.

Clark, S.M., LeDoux, D.G., Seeno, T.N., Riley, E.G., Gilbert A.J., and Sullivan J.M. 2004. Host plants of leaf beetle species occurring in the United States and Canada. Special Publication No. 2. The Coleopterists Society, Sacramento, California, United States of America. 
Deczynski, A.M. 2014. A preliminary revision of the genus Epitrix Foudras (Coleoptera: Chrysomelidae: Galerucinae: Alticini) in America north of Mexico. Thesis. University of Delaware, United States of America. Available from http://dspace.udel.edu/bitstream/handle/ 19716/13155/Deczynski\%2c\%20Anthony.pdf?sequence=1 [accessed 31 July 2020].

Deczynski, A.M. 2019. The Palearctic flea beetle Epitrix pubescens (Koch) (Coleoptera: Chrysomelidae: Galerucinae: Alticini) established in North America. Insecta Mundi, 1207: 1-5.

de Tonnancour, P., Anderson, R.S., Bouchard, P., Chantal, C., Dumont, S., and Vigneault, R. 2017. New Curculionoidea (Coleoptera) records for Québec, Canada. ZooKeys, 681: 95-117.

Döberl, M. 2010. Alticinae. In Catalogue of Palaearctic Coleoptera. Volume 6. Chrysomeloidea. Edited by I. Löbl and A. Smetana. Apollo Books, Stenstrup, Denmark. Pp. 491-563.

Doguet, S. 1994. Coléoptères Chrysomelidae. Alticinae. Faune de France. Volume 2. Fédération Française des Sociétés de Sciences Naturelles, Paris, France.

Douglas, H. 2011. New records of European wireworm pests and other click beetles (Coleoptera: Elateridae) in Canada and USA. Journal of the Entomological Society of Ontario, 142: 11-17.

Hebert, P.D.N., Penton, E.H., Burns, J.M., Janzen, D.H., and Hallwachs, W. 2004. Ten species in one: DNA barcoding reveals cryptic species in the neotropical skipper butterfly Astraptes fulgerator. Proceedings of the National Academy of Sciences of the United States of America, 101: 14812-14817.

Hendrich, L., Morinière, J., Haszprunar, G., Hebert, P.D.N., Hausmann, A., Köhler, F., and Balke, M. 2015. A comprehensive DNA barcode database for Central European beetles with a focus on Germany: adding more than 3500 identified species to BOLD. Molecular Ecology Resources, 15: 795-818.

Hoebeke, E.R., Wheeler, Jr., A.G., Kingsolver, J.M., and Stephan, D.L. 2009. First North American records of the east Palearctic seed beetle Bruchidius terrenus (Coleoptera: Chrysomelidae: Bruchinae), a specialist on mimosa (Albizia julibrissin, Fabaceae). Florida Entomologist, 92: 434-440.

Hornfeldt, C.S. and Collins, J.E. 1990. Toxicity of nightshade berries (Solanum dulcamara) in mice. Journal of Toxicology: Clinical Toxicology, 28: 185-192.

Kingsolver, J.M. 2004. Handbook of the Bruchidae of the United States and Canada (Insecta: Coleoptera). Volume 1. United States Department of Agriculture, Agricultural Research Service, Springfield, Virginia, United States of America. Technical Bulletin 1912. 324 pp.

Klimaszewski, J., Hoebeke, E.R., Langor, D.W., Douglas, H.B., Borowiec, L., Hammond, H.E.J., et al. 2020. Synopsis of adventive species of Coleoptera (Insecta) recorded from Canada. Part 5. Chrysomeloidea (Cerambycidae, Chrysomelidae, and Megalopodidae). Advanced Books, Sofia, Bulgaria. https://doi.org/10.3897/ab.e50613.

Lopatin, I.K., Smetana, A., and Schöller, M. 2010. Tribe Cryptocephalini Gyllenhal, 1813, genus Cryptocephalus Geoffroy, 1762. In Catalogue of Palaearctic Coleoptera. Volume 6. Chrysomeloidea. Edited by I. Löbl and A. Smetana. Apollo Books, Stenstrup, Denmark. Pp. 580-606.

Mason, P.G. and Gillespie, D.R. 2013. Biological control programmes in Canada, 2001-2012. CABI Publishing, Wallingford, United Kingdom.

Mason, P.G. and Huber, J.T. 2002. Biological control programmes in Canada, 1981-2000. CABI Publishing, Wallingford, United Kingdom.

Mohr, K.H. 1966. Familie Chrysomelidae. In die Käfer Mitteleuropas. Volume 9. Edited by H. Freude, K.W Harde, and G.A. Lohse. Goecke and Evers, Krefeld, Germany. 299 pp.

Myers, J.H. and Sarfraz, R.M. 2017. Impacts of insect herbivores on plant populations. Annual Review of Entomology, 62: 207-230.

Nadein, K.S. 2010. A review of the genus Psylliodes Latreille (Coleoptera, Chrysomelidae) of the fauna of Russia and neighboring countries. Part II. An annotated list of species. Entomological Review, 90: 1035-1074. 
Overholt, W.A., Diaz, R., Hibbard, K.L., Roda, A.L., Amalin, D., Fox, A.J., et al. 2009. Releases, distribution and abundance of Gratiana boliviana (Coleoptera: Chrysomelidae), a biological control agent of tropical soda apple (Solanum viarum, Solanaceae) in Florida. The Florida Entomologist, 92: 450-457, 458.

Overholt, W.A., Rayamajhi, M., Rohrig, E., Hight, S., Dray, F.A., Lake, E., et al. 2016. Release and distribution of Lilioceris cheni (Coleoptera: Chrysomelidae), a biological control agent of air potato (Dioscorea bulbifera: Dioscoreaceae), in Florida. Biocontrol Science and Technology, 26: 1087-1099.

Paine, T.D., Millar, J.G., and Daane, K.M. 2010. Accumulation of pest insects on Eucalyptus in California: random process or smoking gun? Journal of Economic Entomology, 103: 1943-1949.

Pentinsaari, M., Anderson, R., Borowiec, L., Bouchard, P., Brunke, A., Douglas, H., et al. 2019. DNA barcodes reveal 63 overlooked species of Canadian beetles (Insecta, Coleoptera). ZooKeys, 894: 53-150.

Pentinsaari, M., Hebert, P.D.N., and Mutanen, M. 2014. Barcoding beetles: a regional survey of 1872 species reveals high identification success and unusually deep interspecific divergences. PLOS One, 9: e108651.

Quinn, M. 2017. North American Cryptocephalus species (Chrysomelidae, Cryptocephalinae) arranged by species groups with comments by White (1968). Texas Beetle Resources. Available from http://texasento.net/Crypto.html [accessed 31 July 2020].

Ratnasingham, S. and Hebert, P.D.N. 2007. BOLD: The barcode of life data system (http://www. barcodinglife.org). Molecular Ecology Notes, 7: 355-364.

Ratnasingham, S. and Hebert, P.D.N. 2013. A DNA-based registry for all animal species: the barcode index number (BIN) system. PLOS One, 8: e66213.

Regalin, R. and Medvedev, L.N. 2010. Cryptocephalinae: Clytrini. In Catalogue of Palaearctic Coleoptera. Volume 6. Chrysomeloidea. Edited by I. Löbl and A. Smetana. Apollo Books, Stenstrup, Denmark. Pp. 564-580.

Reid, C.A.M. 1988. Diachus auratus (F.) (Coleoptera: Chrysomelidae), a recent immigrant to the south-west Pacific region, on legumes. General and Applied Entomology, 20: 5-8.

Rheinheimer, J. and Hassler, M. 2018. Die Blattkäfer Baden-Württembergs. Kleinsteuber Books, Karlsruhe, Germany.

Riley, E.G., Clark, S.M., and Seeno, T.N. 2003. Catalog of leaf beetles of America north of Mexico (Coleoptera: Megalopodidae, Orsodacnidae and Chrysomelidae, excluding Bruchinae). Special Publication No. 2. The Coleopterists Society, Sacramento, California, United States of America.

Schöller, M., Löbl, I., and Lopatin, I.K. 2010. Cryptocephalinae: Cryptocephalini (excl. Cryptocephalus). In Catalogue of Palaearctic Coleoptera. Volume 6. Chrysomeloidea. Edited by I. Löbl and A. Smetana. Apollo Books, Stenstrup, Denmark. Pp. 580-617.

Tracy, J.L. and Robbins, T.O. 2009. Taxonomic revision and biogeography of the Tamarix-feeding Diorhabda elongata (Brulle, 1832) species group (Coleoptera: Chrysomelidae: Galerucinae: Galerucini) and analysis of their potential in biological control of tamarisk. Zootaxa, 2101: 1-152.

Waggy, M.A. 2009. Solanum dulcamara. In Fire effects information system. United States Department of Agriculture Forest Service, Rocky Mountain Research Station, Fire Sciences Laboratory, Fort Collins, Colorado, United States of America. Available from https://www.fs. fed.us/database/feis/plants/shrub/soldul/all.html [accessed 31 July 2020].

White, R.E. 1968. A review of the genus Cryptocephalus in America north of Mexico (Chrysomelidae: Coleoptera). United States National Museum Bulletin, 290: 1-124.

Cite this article: Douglas, H.B., Dumont, S., Savard, K., and Chantal, C. 2021. Two adventive species of European Chrysomelidae (Coleoptera) new to North America: Cryptocephalus moraei (Cryptocephalinae) and Psylliodes dulcamarae (Galerucinae: Alticini), and the origins of adventive Chrysomelidae in Canada and United States of America. The Canadian Entomologist, 153: 774-786. https://doi.org/10.4039/tce.2021.20. 